\title{
ANALISIS KESALAHAN MAHASISWA MENURUT TAHAPAN KASTOLAN DAN PEMECAHAN MASALAH MATEMATIKA FINANSIAL MODEL POLYA
}

\author{
Julia Noviani \\ Sekolah Tinggi Agama Islam Negeri Gajah Putih, Jalan Yos Sudarso, Takengon 24552, Indonesia \\ Email: julianoviani@gmail.com
}

\begin{abstract}
Abstrak
Penelitian ini bertujuan untuk menganalisis kesalahan mahasiswa dalam memecahkan masalah pada mata kuliah matematika finansial berdasarkan model Polya dan tahapan kesalahan Kastolan. Penelitian dilakukan di Sekolah Tinggi Agama Islam Negeri Gajah Putih Takengon dengan subjek penelitian mahasiswa program studi Perbankan Syariah yang berjumlah 9 orang. Metode yang digunakan adalah kualitatif deskriptif. Instrumen pengumpulan data adalah soal tes yang terdiri dari 3 soal dan wawancara tidak terstruktur. Berdasarkan tahapan Kastolan, jenis kesalahan dibedakan menjadi 3 jenis, yaitu kesalahan konsep, kesalahan hitung dan kesalahan strategi. Kesalahan yang paling banyak dilakukan adalah kesalahan hitung yaitu sebanyak 11 kasus atau 45,83\% dari semua kesalahan. Kesalahan konsep yang dilakukan oleh mahasiswa sebanyak 10 kasus atau 41,67\% dan kesalahan strategi sebanyak 3 kasus atau $12,50 \%$ dari semua kesalahan. Tahapan pemecahan masalah berdasarkan tahapan Polya yang ditemukan kesulitannya adalah tahapan memahami masalah, pada tahapan ini mahasiswa tidak mampu menemukan fakta dan informasi yang terdapat dalam soal. Tahapan merancang suatu rencana, mahasiswa tidak dapat mengaitkan fakta-fakta yang di dapat dengan fakta lain secara tepat. Tahapan menyelesaikan rencana, belum mampu menghubungkan konsep-konsep matematika yang telah dipelajari sebelumnya untuk menyelesaikan masalah. Tahapan memeriksa kembali, mahasiswa terkesan terburu-buru dan kurang teliti sehingga tidak memeriksa kembali langkah-langkah pengerjaan yang dilakukan.
\end{abstract}

Kata kunci: Jenis Kesalahan, Tahapan Kastolan, Pemecahan Masalah Polya

\begin{abstract}
This study aims to analyze the student errors in problem solving in financial mathematics based on the Polya model and Kastolan error steps. The study was conducted at Sekolah Tinggi Gajah Putih Takengon which those subject 9 students of Islamic Finance program. This research used qualitative descriptive approach. The instruments to collect data are test question which are consist of 3 questions and unstructured interview. Based on the stages of Kastolan, the types of errors are divided into 3 types, namely conceptual errors, calculation errors and strategy errors. The most common mistake is calculation error, which is 11 cases or $45.83 \%$ of all errors. Concept errors made by students are 10 cases or $41.67 \%$ and strategy errors are 3 cases or $12.50 \%$ of all errors. The steps of problem solving based on Polya which found difficulties are the steps of understanding the problem, at this step, students were unable to find the facts and information contained in the problem. The step of devising a plan, students cannot associate the facts obtained with other facts appropriately. The step of carry out the plan, have not been able to connect the mathematical concepts that have been studied before to solve the problem. During the looking back step, the students seemed to be in a hurry and not careful so they did not check the step taken.
\end{abstract}

Keywords: Types of Error, Kastolan Steps, Polya's Problem Solving.

\section{PENDAHULUAN}

Matematika adalah ilmu dasar yang sangat berpengaruh terhadap berbagai disiplin ilmu. Berbagai rumus, inisial, teorema dan konsep dalam matematika digunakan dalam perhitungan dan penilaian di berbagai bidang, salah satunya adalah matematika finansial. Matematika finansial merupakan sebuah mata kuliah yang hampir ada pada setiap perguruan tinggi terutama pada jurusan 
ekonomi dan syariah. Matematika finansial juga menjadi salah satu mata kuliah keahlian yang wajib diambil dan dituntaskan (lulus) oleh mahasiswa yang mengambil jurusan ekonomi dan syariah, salah satunya adalah mahasiswa yang kuliah pada jurusan syariah dengan program studi perbankan syariah. Mata kuliah matematika finansial membahas tentang pengukuran dan pemecahan masalah, masalah bunga, anuitas, amortisasi, aplikasi anuitas dan bunga majemuk, nilai sekarang dari uang, matematika dalam pasar modal. Penekanan pada teori dasar, pembuktian dan perhitungan ini menyebabkan mahasiswa senantiasa mengalami kesulitan dalam memahami mata kuliah matematika finansial. Materi-materi pokok pada mata kuliah ini merupakan dasar konsep yang akan digunakan pada praktik-praktik lapangan yang akan dilaksanakan oleh mahasiswa. Mengingat betapa pentingnya mata kuliah matematika finansial, maka diharapkan mahasiswa memiliki kemampuan pemahaman dan peguasaan yang baik dalam mata kuliah ini.

Sebagai usaha untuk meningkatkan penguasaan mahasiswa pada mata kuliah matematika finansial, maka salah satu cara yang dapat dilakukan oleh dosen sebagai tenaga pengajar adalah melakukan penelitian terhadap penguasaan mahasiswa tersebut. Penelitian tersebut salah satunya berupa penelitian terhadap kesalahan mahasiswa dalam memecahkan soal-soal matematika finansial. Hasil akhir dari penelitian ini dapat memberikan gambaran tentang jenis kesalahan yang dilakukan, sehingga dosen dapat mengatur strategi yang lebih tepat karena fokus permasalahan menjadi lebih sempit. Gambaran kesalahan akan terlihat pada jawaban mahasiswa terhadap soal-soal matematika finansial yang berbentuk soal cerita.

Kesalahan dalam memecahkan masalah matematika sering terjadi, baik secara tulisan dan lisan, khususnya pada soal-soal yang berbentuk soal cerita. Pemecahan masalah matematika adalah keterampilan yang sangat kompleks. Pernyataan tersebut dikuatkan oleh pendapat Wilson, Fernandez, \& Hadaway (dalam Bhat, 2014:685) yang menyatakan bahwa "Problem solving has a special importance in the study of mathematics. A primary goal of mathematics teaching and learning is to develop the ability to solve a wide variety of complex mathematics problems". Memnun, dkk (2012) mengemukakan bahwa memungkinkan individu untuk mendapatkan keterampilan pemecahan masalah dan melatih individu yang bisa mengatasi masalah yang dihadapi selama kehidupan nyata mereka, adalah tujuan prioritas dan tujuan utama dari pendidikan saat ini. Hal ini menunjukkan bahwa keterampilan pemecahan masalah memiliki peranan yang sangat penting dalam proses pengajaran dan pembelajaran. Hal tersebut ditegaskan dengan pernyataan Foshey bahwa pemecahan masalah adalah keterampilan dasar yang dibutuhkan oleh peserta didik saat ini dan pemecahan masalah menjadi fokus utama dari kurikulum matematika. Senada dengan itu Holmes (dalam NCTM, 1980) menyatakan bahwa pemecahan masalah adalah "jantung" dari matematika. Meskipun pemecahan masalah menjadi "jantung" dari matematika, masih banyak siswa mengalami kesulitan dalam memecahkan masalah dalam bentuk soal cerita, antara lain memahami dan membuat generalisasi tentang keterampilan dan konsep matematika, dan konsep atau prosedur matematika. Langkah pemecahan masalah menurut 
Polya sebagai berikut: memahami masalah (understand the problem), merancang suatu rencana (devise a plan), menyelesaikan rencana (carry out the plan), memeriksa kembali (look back).

Soejadi (2000:3) menyatakan bahwa karakteristik matematika meliputi objek abstrak, bertumpu pada kesepakatan, berpola pikir deduktif, memiliki simbol yang kosong dari arti, memperhatikan semesta pembicaraan dan konsisten dalam sistemnya. Objek abstrak matematika terdiri dari fakta, konsep, operasi dan prinsip. Objek abstrak matematika tersebut dapat diamati saat seseorang sedang atau telah memecahkan soal-soal matematika. Jika dalam proses pengerjaan atau pemecahan masalah matematika tidak menggunakan objek abstrak matematika tersebut maka dapat dinyatakan individu tersebut telah mengalami kesalahan atau terdapat kekurangan dalam proses pemecahan masalah tersebut. Radatz (1980:16) menyatakan bahwa kesalahan mahasiswa "menggambarkan" kesulitan individu, mereka menunjukkan bahwa mahasiswa gagal memahami atau memahami konsep, teknik dan masalah tertentu.

Senada dengan pendapat di atas, Kastolan (1992) membedakan jenis kesalahan menjadi tiga yaitu kesalahan konseptual, kesalahan strategi dan kesalahan teknik. Kesalahan konseptual mencakup: (a) kesalahan dalam penggunaan rumus atau definisi dalam menjawab soal; (b) menggunakan rumus atau definisi yang tidak sesuai dengan kondisi atau prasyarat berlakunya rumus. Kesalahan strategi yaitu: (a) dalam pengerjaan soal, langkah-langkah tidak sistematis; (b) tidak dapat atau melakukan kesalahan dalam manipulasi langkah-langkah pengerjaan soal. Kesalahan hitung merupakan kesalahan dalam menghitung untuk memecahkan suatu soal. Kesalahan-kesalahan yang dilakukan dalam belajar matematika, tidak terlepas dari karakteristik matematika itu sendiri. Berdasarkan uraian penjelasan di atas, maka peneliti tertarik untuk melakukan penelitian dengan judul "Analisis kesalahan mahasiswa menurut tahapan kastolan dan pemecahan masalah model polya pada mata kuliah matematika finansial". Tujuan dari penelitian ini adalah untuk menganalisis kesalahan mahasiswa dalam memecahkan masalah pada mata kuliah matematika finansial berdasarkan model Polya dan tahapan kesalahan Kastolan.

\section{METODE PENELITIAN}

\section{Rancangan Penelitian}

Penelitian ini merupakan jenis penelitian deskriptif. Pendekatan yang digunakan dalam penelitian ini adalah kualitatif deskriptif. Peneliti selain sebagai pengumpul data dan penganalisis data juga terlibat langsung dalam penelitian (Moleong, 2006). Fenomena yang diamati dan dikaji pada penelitian adalah kesalahan mahasiswa dalam memecahkan soal matematika finansial berdasarkan tahapan Kastolan dan pemecahan masalah Polya. Subjek penelitian ini adalah mahasiswa Perbankan Syariah di Sekolah Tinggi Agama Islam Negeri Gajah Putih Takengon. Mahasiswa yang diambil adalah mahasiswa semester III tahun ajaran 2018/2019 sebanyak 9 orang. Mahasiswa semester III ini dipilih karena telah mengambil mata kuliah matematika finansial dengan kemampuan tinggi, 
kemampuan sedang dan kemampuan rendah. Penelitian dilaksanakan saat ujian akhir semester ganjil 2019 berakhir, yaitu pada tanggal 18 Januari - 13 Februari 2019.

Instrumen utama dalam penelitian ini adalah peneliti sendiri, karena peneliti sebagai alat pengumpul data yang utama. Peneliti berperan sebagai perancang, pengumpul data, analisator, penafsir dan akhirnya menyimpulkan hasil penelitian. Instrumen pendukung dalam penelitian ini adalah soal tes pemecahan masalah dan wawancara tidak terstruktur. Teknik pengumpulan data meliputi tes pemecahan masalah dan wawancara. Prosedur penelitian dimulai dengan melakukan tes pada mahasiswa semester III. Soal tes terdiri dari 3 soal matematika finansial. Hasil tes dan wawancara mahasiswa akan dianalisis dan diidetifikasi kesalahannya. Pada penelitian ini jenis kesalahan diklasifikasikan menurut tahapan Kastolan dan tahapan pemecahan masalah akan menggunakan tahapan pemecahan masalah Polya. Berikut adalah soal tes mahasiswa:

Tabel 1. Soal Tes Matematika Finansial

\begin{tabular}{|c|c|}
\hline No & Soal \\
\hline 1 & $\begin{array}{l}\text { Harga sebuah printer adalah } \mathrm{Rp} 7.000 .000,00 \text {. Diestimasikan bahwa } \\
\text { printer ini dapat digunakan sengan baik selama } 3 \text { tahun dengan } \\
\text { kemampuan mencetak } 150.000 \text { lembar kertas. Setelah masa manfaatnya } \\
\text { habis, printer tersebut diharapkan dapat terjual dengan harga Rp } \\
700.000,00 \text { (estimasi nilai sisa). Jika tahun ke-1 mencetak } 80.000 \text { lembar, } \\
\text { tahun ke-2 mencetak 50.000 lembar dan tahun ke-3 mencetak } 20.000 \\
\text { lembar, maka hitunglah depresiasi per tahunnya! }\end{array}$ \\
\hline 2 & $\begin{array}{l}\text { Riko membeli kendaraan seharga } \mathrm{Rp} 24.000 .000,00 \text { yang ia lunasi } \\
\text { sebanyak } 4 \text { kali cicilan selama } 2 \text { tahun, dengan tingkat bunga } 5 \% \text {, } \\
\text { berapakah sisa hutang Riko pada akhir tahun pertama? (buat tabel } \\
\text { amortisasi). }\end{array}$ \\
\hline 3 & $\begin{array}{l}\text { Seorang pedagang membeli } 2 \text { buah toko seharga Rp } 980.000 .000,00 \\
\text { dengan membayarkan uang muka sebesar Rp } 230.000 .000,00 \text { dan sisanya } \\
\text { dicicil setiap bulan selama } 17 \text { tahun dengan tingkat bunga } 12 \% \\
\text { perhitungan bulanan. Berapakah besarnya cicilan yang harus dibayarkan } \\
\text { setiap bulan? }\end{array}$ \\
\hline
\end{tabular}

\section{HASIL PENELITIAN DAN PEMBAHASAN}

Berdasarkan hasil jawaban tes oleh mahasiswa, berikut hasil analisis kesalahan mahasiswa dalam memecahkan soal matematika finansial:

Tabel 2. Hasil Jawaban Mahasiswa

\begin{tabular}{|c|c|c|c|c|}
\hline \multirow{2}{*}{$\begin{array}{c}\text { Inisial } \\
\text { Mahasiswa }\end{array}$} & \multirow{2}{*}{$\begin{array}{c}\text { Kemampuan } \\
\text { Mahasiswa } \\
\text { (sebelumnya) }\end{array}$} & \multicolumn{3}{|c|}{ Jenis Kesalahan } \\
\cline { 3 - 5 } & Tinggi & Soal 1 & Soal 2 & Soal 3 \\
\hline ESB & Tinggi & Konsep & Hitung & Hitung \\
\hline ZE & Tinggi & Hitung & Konsep & Hitung \\
\hline SY & Tinggi & - & Hitung & Hitung \\
\hline IAF & Sedang & Konsep & Konsep & Honsep \\
\hline SJ & Sedang & Strategi & Konsep & - \\
\hline AS & & & &
\end{tabular}




\begin{tabular}{|c|c|c|c|c|}
\hline \multirow{2}{*}{$\begin{array}{c}\text { Inisial } \\
\text { Mahasiswa }\end{array}$} & \multirow{2}{*}{$\begin{array}{c}\text { Kemampuan } \\
\text { Mahasiswa } \\
\text { (sebelumnya) }\end{array}$} & \multicolumn{3}{|c|}{ Jenis Kesalahan } \\
\cline { 3 - 5 } & Soal 1 & Soal 2 & Soal 3 \\
\hline HP & Rendah & Konsep & Konsep & Strategi \\
\hline KR & Rendah & Strategi & Hitung & Hitung \\
\hline SM & Rendah & Hitung & Konsep & - \\
\hline
\end{tabular}

Mahasiswa yang mengalami kesalahan konsep pada soal nomor 1 sebanyak 44,4 \% mahasiswa, kemudian mahasiswa yang mengalami kesalahan hitung sebanyak $22,2 \%$, dan mahasiswa yang mengalami kesalahan strategi yaitu sebanyak $22,2 \%$, sedangkan satu mahasiswa tidak menjawab pertanyaan nomor 1 . Untuk soal nomor 2 , mahasiswa yang mengalami kesalahan konsep sebanyak $55,6 \%$ dan mahasiswa yang mengalami kesalahan hitung sebanyak 44,4\% mahasiswa. Pada soal nomor 2 ini tidak ada mahasiswa yang tidak menjawab pertanyaan walaupun masih terdapat kesalahan. Untuk soal nomor 3, mahasiswa yang mengalami kesalahan konsep sebanyak 11,1\% mahasiswa, mahasiswa yang mengalami kesalahan strategi sebanyak 11,1\%, dan kesalahan hitung sebanyak 55,6 \%, sedangkan ada dua orang mahasiswa yang tidak menjawab pertanyaan pada soal nomor 3.

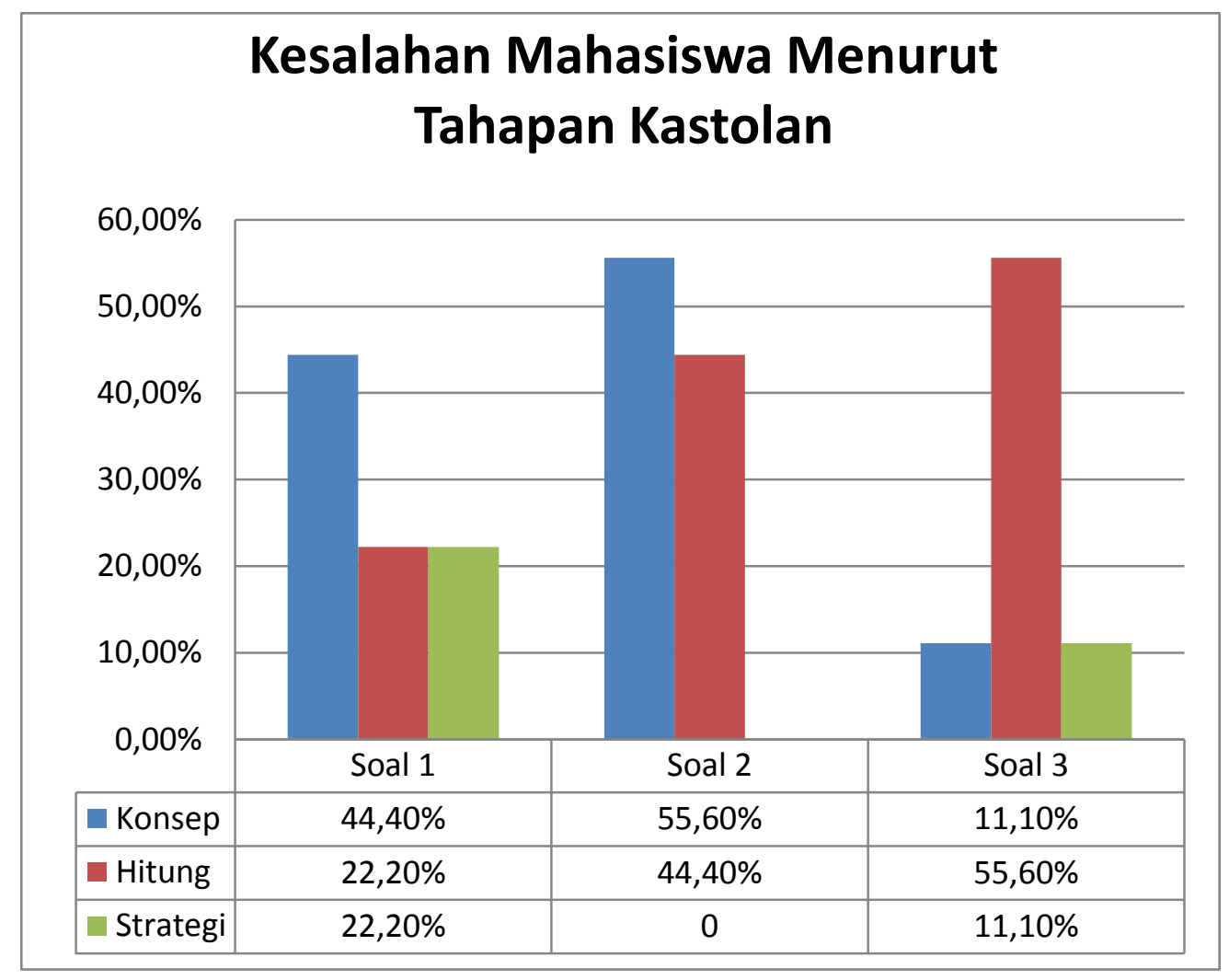

Gambar 1. Diagram Batang Kesalahan Mahasiswa Menurut Tahapan Kastolan

Berdasarkan Tabel 2 dari total 27 jawaban, mahasiswa membuat 24 kesalahan. Kesalahan yang paling banyak dilakukan adalah kesalahan hitung yaitu sebanyak 11 kasus atau 45,83\% dari semua 
kesalahan. Hal ini sama seperti penelitian yang dilakukan oleh Arigiyanti (2017) dimana mahasiswa paling banyak mengalami kesalahan komputasi/hitung yaitu 68,79\% (Arigiyanti, 2017). Kesalahan konsep yang dilakukan oleh mahasiswa sebanyak 10 kasus atau 41,67\% dan kesalahan strategi sebanyak 3 kasus atau 12,50\% dari semua kesalahan.

\section{Kesalahan Konsep}

Kesalahan konsep yang terjadi antara lain kesalahan dalam konsep amortisasi, sisa hutang dan depresiasi. Beberapa mahasiswa tidak paham dengan konsep amortisasi, menghitung sisa hutang dan depresiasi sehingga tidak mampu memecahkan masalah. Berikut merupakan contoh hasil pekerjaan mahasiswa yang mengalami kesalahan konsep:

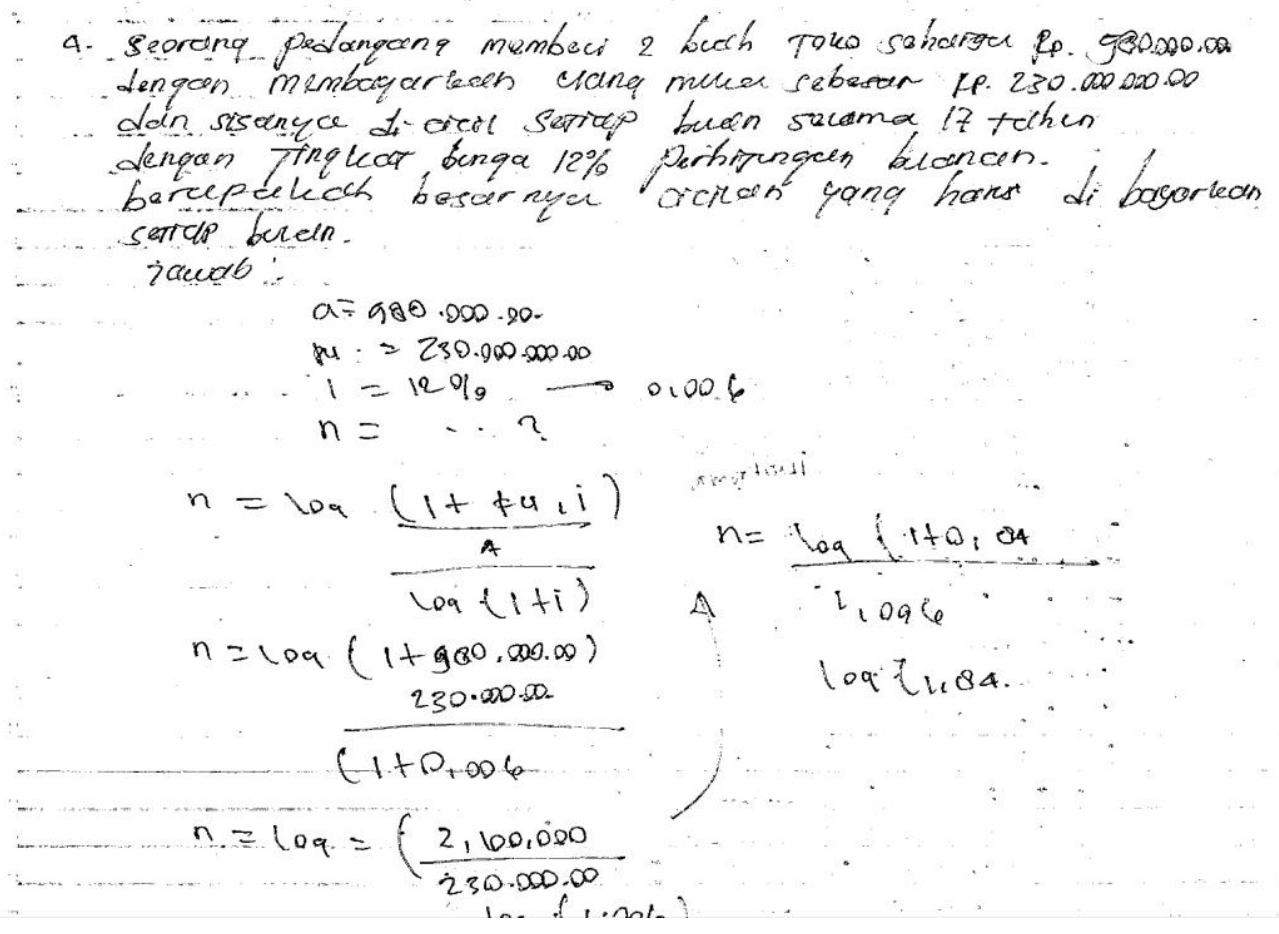

Salah satu indikator kesalahan konsep menurut Kastolan (1992) adalah menggunakan rumus/definisi yang tidak sesuai dengan kondisi atau prasyarat berlakunya rumus. Dari gambar 2, subjek HP yang memiliki kemampuan rendah terlihat menggunakan rumus yang tidak sesuai dengan kondisi masalah yang berlaku. Subjek HP menggunakan rumus perhitungan jumlah periode tabungan pada masalah amortisasi, sehingga jelas terlihat bahwa ia mengalami kesalahan konsep.

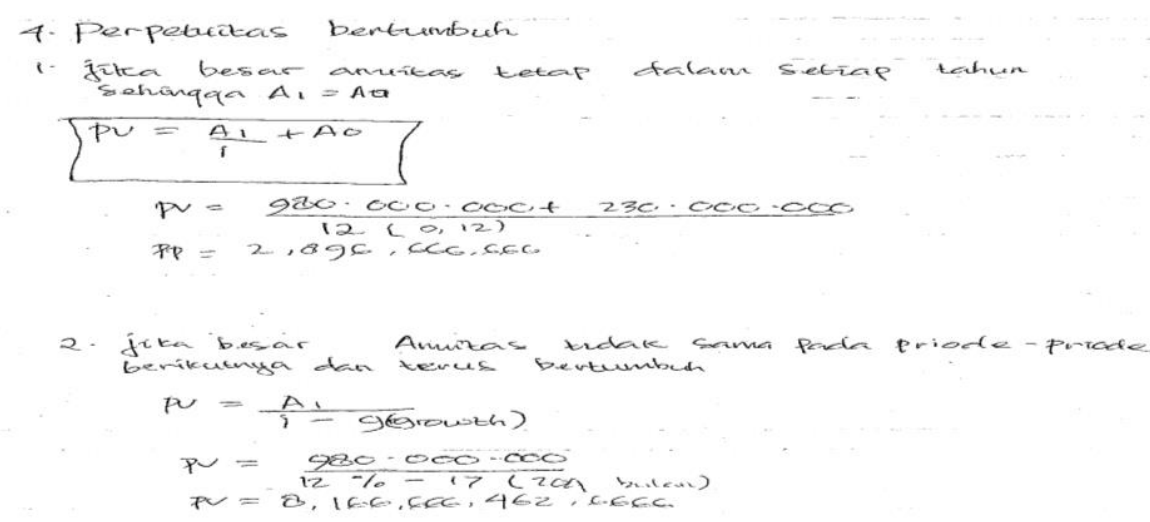


Kesalahan konsep juga terjadi pada subjek ESB yang memiliki kemampuan tinggi. Subjek ESB menggunakan rumus perpetuitas bertumbuh pada masalah amortisasi sehingga subjek tersebut juga mengalami kesalahan konsep.

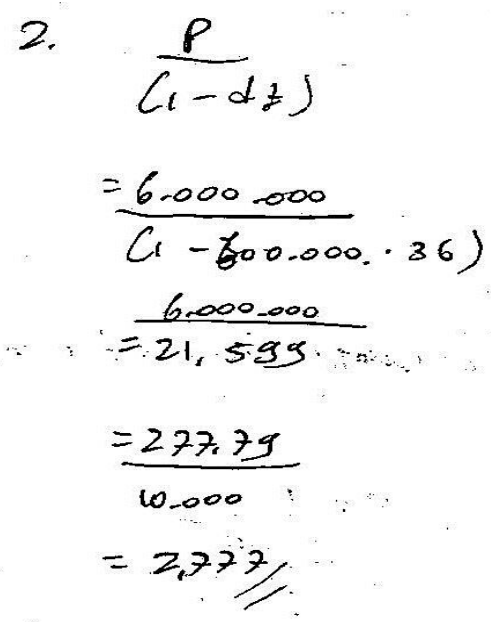

Gambar 4. Hasil Jawaban Subjek SJ

Selanjutnya subjek SJ yang memiliki kemampuan sedang menggunakan rumus tingkat diskon dalam permasalahan depresiasi, padahal bahasan materi yang sangat jauh berbeda, sehingga subjek SJ melakukan kesalahan konsep yang sangat fatal. Ketika dilakukan wawancara dengan mahasiswa yang melakukan kesalahan konsep, mereka menjawab karena tidak paham dengan rumus amortisasi sehingga terjadilah kesalahan konsep.

Terlihat dari jawaban yang ditulis oleh mahasiswa, mereka tidak memahami masalah dengan baik. Subjek HP, subjek ESB dan subjek SJ tidak mampu menuliskan informasi yang diketahui dan ditanya dari soal. Karena hal tersebut, ketiga subjek juga mengalami kesalahan pada tahapan merancang suatu rencana. Mereka kesulitan dalam merancang rencana karena tidak terbiasa dan langsung mengerjakan soal tanpa membuat rencana terlebih dahulu. Pada tahap melaksanakan rencana, misalkan subjek HP, ia menggunakan rumus perhitungan jumlah periode tabungan yang jelas sangat berbeda dengan masalah amortisasi. Berikut hasil petikan wawancara dengan subjek HP.

Peneliti : Apa yang diketahui dari soal?

Subjek : Hmm. Bingung bu.

Peneliti : Coba dibaca baik-baik soalnya.

Subjek : (sambil membaca soal)

Peneliti : Bagaimana? Apa yang diketahui dari soal?

Subjek : 2 buah toko harganya Rp 980.000.000, uang muka sebesar Rp 230.000.000 kemudian dicicil setiap bulan selama 17 tahun dengan tingkat bunga $12 \%$ perhitungan bulanan.

Peneliti : Oke, dan apa yang ditanya?

Subjek : Besarnya cicilan yang harus dibayarkan setiap bulan

Peneliti : Kira-kira paham dengan soalnya?

Subjek : Masih bingung Bu

Peneliti : Simbolnya tahu?

Subjek : Tidak Bu. 
Peneliti : Mengapa membingungkan?

Subjek : Saya sulit memahami soal dalam bentuk cerita bu.

Berdasarkan hasil wawancara subjek HP mengatakan bahwa ia mengalami kesulitan dalam memahami soal cerita. Hal ini senada yang disampaikan Gooding bahwa kesulitan siswa dalam menyelesaikan soal cerita diantaranya adalah membaca dan memahami, membaca semua informasi, informasi yang mengganggu perhatian, membayangkan konteks, menulis kalimat matematika, perhitungan dan menerjemahkan jawaban. Pada tahap memeriksa kembali, subjek HP tidak memeriksa kembali langkah-langkah yang ia kerjakan dari awal hingga akhir.

\section{Kesalahan Hitung}

Kesalahan hitung merupakan kesalahan yang paling banyak dilakukan oleh mahasiswa yaitu sebanyak 11 kasus atau 45,83\% dari total kesalahan. Kesalahan hitung yang terjadi antara lain adalah perkalian, cara mengubah persen ke pecahan desimal dan perpangkatan. Berikut adalah contoh subjek SY yang memiliki kemampuan tinggi dan melakukan kesalahan hitung pada perkalian.

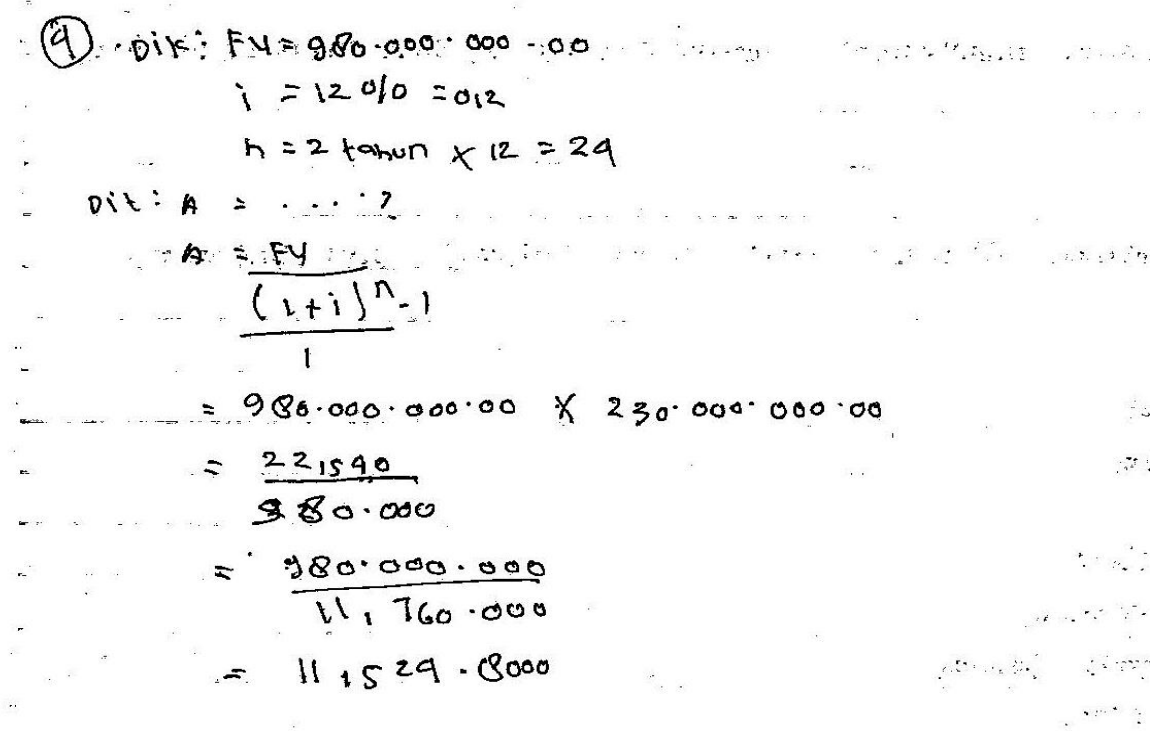

Gambar 5. Hasil Jawaban Subjek SY

Kemudian ada 4 mahasiswa yang mengalami kesalahan hitung pada cara mengubah persen ke pecahan desimal. Berikut adalah gambar subjek yang melakukan kesalahan hitung pada cara mengubah persen ke pecahan desimal. 


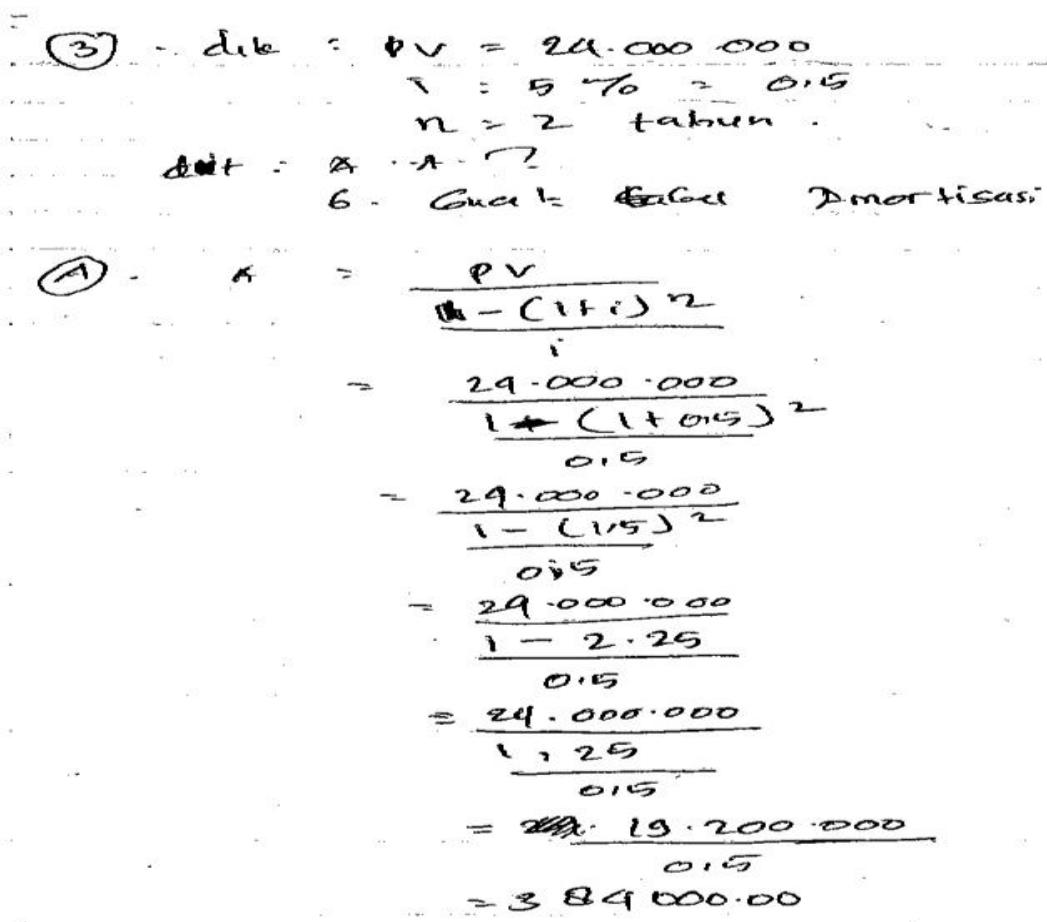

Gambar 6. Hasil Jawaban Subjek IAF

Ketika dilakukan wawancara pada mahasiswa yang melakukan kesalahan hitung, alasannya adalah karena tidak teliti dan terburu-terburu dalam mencari sehingga terjadilah kesalahan hitung. Subjek IAF yang sebelumnya memiliki kemampuan tinggi terlihat memahami masalah karena ia menuliskan informasi yang diketahui dengan pada soal tersebut. Ia juga merancang rencana yang dilakukan selanjutnya untuk memecahkan soal. Namun saat menyelesaikan rencana tersebut, ia mengalami kesalahan hitung yang awalnya bermula dari kesalahan mengubah persen ke pecahan desimal, $5 \%=0,5$ yang seharusnya $5 \%=0,05$, sehingga kesalahan ini berakibat ke perhitungan selanjutnya. Tahap terakhir, memeriksa kembali dilakukan wawancara terhadap subjek IAF dan berikut adalah hasil petikan wawancara terhadap subjek IAF:

Peneliti : Dari semua langkah-langkah yang kamu kerjakan, apakah kamu memeriksa kembali?

Subjek : Iya bu, saya periksa kembali.

Peneliti : Langkah yang mana yang kamu periksa kembali?

Subjek : Dari mulai diketahui dan ditanya, Bu. Kemudian saya periksa langkah yang menggunakan rumus.

Peneliti : Selanjutnya?

Subjek : Saya periksa lagi rumus yang saya gunakan dan kembali menghitungnya.

Peneliti : Ada yang salah?

Subjek : Setau saya benar Bu.

Peneliti : Yakin?

Subjek : Iya, saya yakin Bu.

Peneliti : Coba dilihat persennya, sudah benar?

Subjek : $5 \%=0,5$, oh sepertinya salah saya Bu, harusnya 0,05.

Peneliti : Nah kan, mengapa bisa salah?

Subjek : Gak teliti bu, buru-buru juga pas mengerjakannya. 
Dari hasil wawancara, subjek IAF mengatakan bahwa ia telah memeriksa semua langkah-langkah pengerjaan soal, namun ia tidak teliti dan terburu-buru dalam memeriksanya. Kesalahan hitung yang dilakukan oleh subjek IAF sangat fatal sehingga mempengaruhi hasil jawaban dari soal tersebut. Dalam melakukan pemeriksaan kembali, mahasiswa tidak terbiasa menggunakan langkah-langkah yang sistematis pada lembar kerja yang digunakan.

\section{Kesalahan Strategi}

Menurut Kastolan kesalahan strategi yaitu: (a) dalam pengerjaan soal, langkah-langkah tidak sistematis; (b) tidak dapat atau melakukan kesalahan dalam manipulasi langkah-langkah pengerjaan soal. Kesalahan yang dilakukan oleh mahasiswa pada penelitian ini adalah tidak dapat memanipulasi langkah-langkah pengerjaan soal. Kesalahan strategi diperlihatkan oleh subjek KR yang memiliki kemampuan rendah dalam gambar berikut:

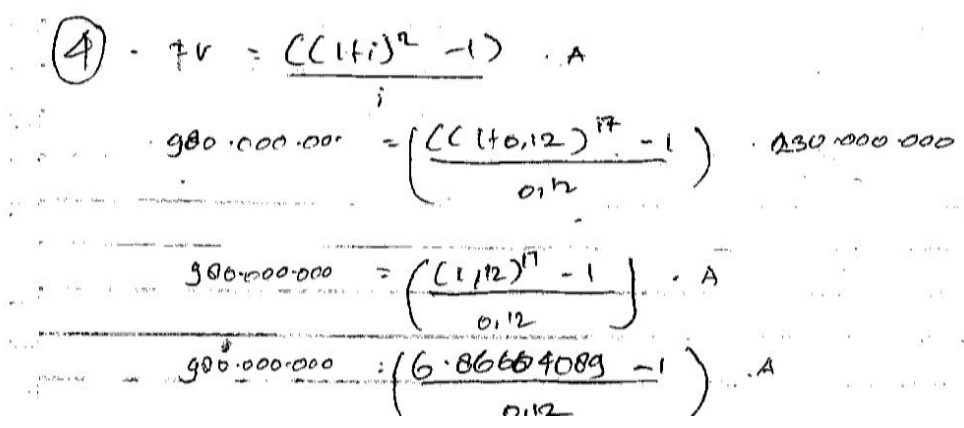

Gambar 7. Hasil Jawaban Subjek KR

Subjek KR tidak dapat memanipulasi langkah pengerjaan pada masalah amortisasi. Terlihat dari Subjek KR tidak menuliskan informasi yang diketahui pada soal, ia langsung menyelesaikan rencana. Namun saat menyelesaikan rencana, ia melakukan kesalahan strategi. Berikut petikan wawancara dengan subjek KR.

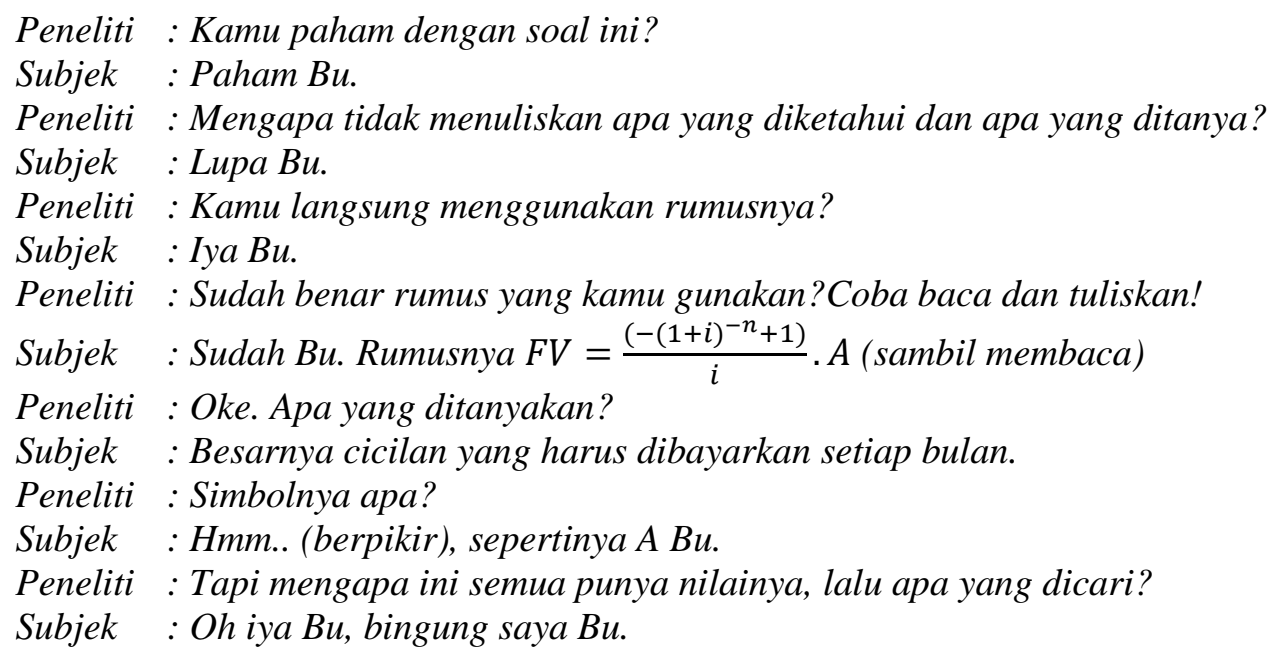

Dari hasil wawancara dengan subjek KR ia terlihat bingung dalam menyelesaikan rencana padahal rumus yang subjek KR gunakan sudah benar. Ia juga tidak menuliskan apa yang diketahui 
dan yang ditanya sebagai informasi awal agar memudahkan subjek KR dalam menyelesaikan rencana. Pada tahapan memeriksa kembali, subjek KR tidak memeriksa kembali langkah-langkah pengerjaan yang telah ia lakukan, sehingga terjadilah kesalahan strategi pada saat ia memecahkan masalah.

\section{Pemecahan Masalah Model Polya}

Pemecahan masalah menurut Polya adalah sebagai usaha mencari jalan keluar dari suatu kesulitan, mencapai suatu tujuan yang tidak dengan segera dapat dicapai. Polya menyatakan bahwa pemecahan masalah merupakan suatu tingkat aktivitas intelektual yang tinggi. Terdapat empat fase pemecahan masalah menurut Polya (1973) sebagai berikut: "In order to group conveniently the questions and suggestions of our list, we shall distinguish four phases of the work. First, we have to understand the problem; we have to see clearly what is required. second, we have to see how the various items are connected, how the unknown is linked to the data, in order to obtain the idea of the solution, to make a plan. Third, we carry out our plan. Fourth, we look back at the completed solution, we review and discuss it."

\section{- Memahami Masalah}

Tahap memahami masalah merupakan tahap yang paling krusial dalam langkah-langkah pemecahan masalah, karena suatu masalah tidak akan terselesaikan jika mahasiswa tidak memahami masalah tersebut. Dari petikan wawancara sebelumnya, subjek HP, ESB, SJ, KR mengalami kesulitan dalam memahami masalah. Mahasiswa tidak menuliskan apa yang diketahui dan apa yang ditanyakan sehingga bermasalah ke tahapan selanjutnya. Penyebab mahasiswa sulit memahami masalah yaitu mahasiswa kurang memahami maksud masalah yang diberikan karena kesulitan atau kendala mengubah kalimat cerita ke model matematika dan mahasiswa terbiasa mengerjakan secara langsung pada proses perhitungannya tanpa menuliskan apa yang diketahui dan ditanyakan terlebih dahulu. Mahasiswa tidak mampu menggemukakan semua fakta dan tidak mengetahui apa yang diminta oleh masalah atau soal. Membaca merupakan kunci dari pemahaman masalah, seorang mahasiswa tidak dapat menyelesaikan masalah apabila mahasiswa tidak paham akan masalah tersebut. Cara memahami masalah adalah dengan membaca dengan seksama. Indikasi lain yang menunjukkan paham atau tidaknya terhadap suatu masalah adalah dengan dituliskannya informasi yang ada pada masalah serta paham mengenai apa yang akan dicari dan dibutuhkan untuk memahamkan masalah tersebut.

\section{- Merancang Suatu Rencana}

Tahapan pemecahan masalah yang kedua adalah merancang suatu rencana, pada penelitian ini mahasiswa tidak dapat menemukan semua fakta yang ada dalam masalah tersebut, dan karena hal tersebut mahasiswa tidak dapat mengaitkan fakta-fakta yang di dapat dengan fakta lain secara tepat, sehingga tidak dapat merancang suatu rencana, seperti subjek HP, ESB, SJ. Seharusnya kemampuan menemukan fakta perlu dimiliki mahasiswa dengan mengaitkan fakta dan informasi yang ada akan memudahkan pengerjaan mahasiswa secara lebih lanjut. 
Proses pengaitan ini diikuti dengan proses pemilihan strategi yang akan digunakan. Pada tahapan merancang suatu rencana ini akan terlihat arah pengerjaan mahasiswa saat memecahkan masalah yang diberikan.

\section{- Menyelesaikan Rencana}

Tahapan penyelesaian rencana atau penyelesaian masalah yaitu mahasiswa menggunakan dan mengembangkan srtrategi matematika yang telah dipilih dengan menyesuaikan fakta yang ada dan dibutuhkan oleh masalah. Namun kenyataannya pada penelitian ini, mahasiswa belum mampu menghubungkan konsep-konsep matematika yang telah dipelajari sebelumnya untuk menyelesaikan masalah, seperti subjek IAF dan KR.

\section{- Memeriksa Kembali}

Tahapan pemecahan masalah yang terakhir yaitu memeriksa kembali hasil perhitungan yang telah diperoleh dan mengkomunikasikan solusi yang didapat. Sering kali mahasiswa merasa tidak cukup dengan penyelesaian masalah berdasarkan fakta yang dimilikinya tanpa memeriksa kembali jawaban yang didapatkannya. Mahasiswa juga sering terburu-buru dan kurang teliti sehingga tidak melakukan tahapan memeriksa kembali, seperti yang dilakukan oleh subjek IAF dan ESB.

\section{KESIMPULAN}

Berdasarkan hasil penelitian, dapat disimpulkan bahwa tipe kesalahan yang dilakukan oleh mahasiswa menurut tahapan Kastolan pada mata kuliah matematika finansial ini adalah kesalahan konsep, kesalahan hitung dan kesalahan strategi. Kesalahan yang paling banyak dilakukan adalah kesalahan hitung yaitu sebanyak 11 kasus atau 45,83\% dari semua kesalahan. Kesalahan konsep yang dilakukan oleh mahasiswa sebanyak 10 kasus atau 41,67\% dan kesalahan strategi sebanyak 3 kasus atau $12,50 \%$ dari semua kesalahan. Tahapan pemecahan masalah berdasarkan tahapan Polya yang ditemukan kesulitannya adalah tahapan memahami masalah, pada tahapan ini mahasiswa tidak mampu menemukan fakta dan informasi yang terdapat dalam soal. Tahapan merancang suatu rencana, mahasiswa tidak dapat mengaitkan fakta-fakta yang di dapat dengan fakta lain secara tepat. Tahapan menyelesaikan rencana, belum mampu menghubungkan konsep-konsep matematika yang telah dipelajari sebelumnya untuk menyelesaikan masalah. Tahapan memeriksa kembali, mahasiswa terkesan terburu-buru dan kurang teliti sehingga tidak memeriksa kembali langkah-langkah pengerjaan yang dilakukan.

Analisis kesalahan ini sebaiknya juga dilakukan pada mata kuliah lainnya agar dosen dapat mengetahui jenis kesalahan mahasiswa serta dapat melaksanakan rencana untuk menangani masalah tersebut. Kemudian, diharapkan mahasiswa untuk lebih sering dihadapkan dengan soal-soal yang mengasah kemampuan memecahkan masalah meliputi memahami masalah, merancang suatu rencana, menyelesaikan rencana dan memeriksa kembali, agar mahasiswa terbiasa menghadapi masalah seperti itu. 


\section{REFERENCES}

Arigiyanti, T. (2017). Identifikasi Kesalahan Mahasiswa dalam Menyelesaikan Soal Pengantar Probabilitas. Jurnal Penelitian Pendidikan, 9(1), 1311-1374.

Bhat, A. M. (2014). Effect of Problem Solving Ability on the Achievement in Mathematics of High School Students (pp. 685-688). India: Aligarh Muslim University, Department of Education.

Foshey, Rob. (2003). Principles for Teaching Problem Solving. Indiana University: Plato Learning.

Gooding, S. (2009). Children's Difficulties with Mathematical Word Problems. Proceedings of British Society for Research into Learning Mathematics.

Kastolan, e. a. (1992). Identifikasi Jenis-jenis Kesalahan Menyelesaikan Soal-Soal Matematika yang Dilakukan Peserta Didik Kelas 2 Program A1 SMA Negeri Se-Kotamadya Malang. Malang: IKIP Malang.

Memnun, D. S., L. C. Hart., \& Akkaya, R. (2012). A Research on the Mathematical Problem Solving Beliefe of Mathematics, Science and Elementary Pre-Service Teacher in Turkey in terms of Different Variables. International Journal of Humanities and Social Science, 2(24), 172-184.

Moleong. (2006). Metodologi Penelitian Kualitatif . Bandung: PT Remaja Rosda Karya.

NCTM. 1980. Problem Solving In School Matehematics. Yearbook: NCTM Inc.

Polya, G. (1973). How to Solve It. New Jersey: Princeton University Press.

Radatz, H. (1980). Students' Errors in the Mathematical Learning Process: a Survey. Journal For the Learning of Mathematics. Qanada: FLM Publishing Co Ltd Montreal Quebec, 10(4), 16-20.

Soedjadi. (2000). Kiat Pendidikan Matematika di Indonesia. Jakarta: Direktorat Jenderal Pendidikan Tinggi Departemen Pendidikan Nasional. 